\title{
Review \\ Variability of Bacterial Homopolysaccharide Production and Properties during Food Processing
}

\author{
Marion Nabot ${ }^{1,2}$, Marie Guérin ${ }^{1,2}$, Dharini Sivakumar ${ }^{3}\left(\mathbb{D}\right.$, Fabienne Remize ${ }^{4}\left(\mathbb{D}\right.$ and Cyrielle Garcia ${ }^{1,2, *(1)}$ \\ 1 QualiSud, University of Montpellier, UMR QualiSud, 34398 Montpellier, France; \\ marion.nabot@cirad.fr (M.N.); marie.guerin@univ-reunion.fr (M.G.) \\ 2 UMR QualiSud, Université de La Réunion, 7 Chemin de l'Irat, F-97410 Saint Pierre, 97410 Réunion, France \\ 3 Department of Horticulture, Tshwane University of Technology, Pretoria 0001, South Africa; \\ SivakumarD@tut.ac.za \\ 4 SPO, Université de Montpellier, INRAE, Institut Agro Montpellier, 34000 Montpellier, France; \\ fabienne.remize@inrae.fr \\ * Correspondence: cyrielle.garcia@univ-reunion.fr
}

check for updates

Citation: Nabot, M.; Guérin, M.; Sivakumar, D.; Remize, F.; Garcia, C. Variability of Bacterial

Homopolysaccharide Production and Properties during Food Processing. Biology 2022, 11, 171. https:// doi.org/10.3390/biology11020171

Academic Editors: Karl Forchhammer and Huizhong Chen

Received: 1 December 2021

Accepted: 18 January 2022

Published: 21 January 2022

Publisher's Note: MDPI stays neutral with regard to jurisdictional claims in published maps and institutional affiliations.

Copyright: (C) 2022 by the authors. Licensee MDPI, Basel, Switzerland. This article is an open access article distributed under the terms and conditions of the Creative Commons Attribution (CC BY) license (https:// creativecommons.org/licenses/by/ $4.0 /$ )
Simple Summary: Bacteria can produce diverse homopolysaccharides (HoPSs), which are polymers of glucose, fructose or galactose. The synthesis of these compounds is catalyzed by glycosyltransferases. The range of HoPS sizes is very large and mostly depends on the carbon source in the medium and the catalyzing enzyme; however, factors such as nitrogen nutrients, $\mathrm{pH}$, water activity, temperature and duration of bacterial culture also impact size and yield. The sequence of the polymerization enzyme influences the structure of the HoPS, by modulating the type of linkage between monomers, both for the linear chain and for the ramifications. HoPSs' size and structure influence its rheological properties. As a consequence, the choice of catalyzing enzyme and the modulation of environmental factors open ways to guide the production of specific HoPSs in foods by bacteria. This approach presents many advantages to propose applications of bacterial HoPS to texture foods, either by in situ or ex situ production, but requires a better knowledge of HoPS production conditions.

Abstract: Various homopolysaccharides (HoPSs) can be produced by bacteria: $\alpha$ - and $\beta$-glucans, $\beta$-fructans and $\alpha$-galactans, which are polymers of glucose, fructose and galactose, respectively. The synthesis of these compounds is catalyzed by glycosyltransferases (glycansucrases), which are able to transfer the monosaccharides in a specific substrate to the medium, which results in the growth of polysaccharide chains. The range of HoPS sizes is very large, from $10^{4}$ to $10^{9} \mathrm{Da}$, and mostly depends on the carbon source in the medium and the catalyzing enzyme. However, factors such as nitrogen nutrients, $\mathrm{pH}$, water activity, temperature and duration of bacterial culture also impact the size and yield of production. The sequence of the enzyme influences the structure of the HoPS, by modulating the type of linkage between monomers, both for the linear chain and for the ramifications. HoPSs' size and structure have an effect on rheological properties of some foods by their influence on viscosity index. As a consequence, the control of structural and environmental factors opens ways to guide the production of specific HoPS in foods by bacteria, either by in situ or ex situ production, but requires a better knowledge of HoPS production conditions.

Keywords: exopolysaccharide; texture; rheology; natural polymers

\section{Introduction}

Homopolysaccharides (HoPSs) or homoglycans are polymeric compounds that have the particularity of being composed of a single type of monosaccharide. They include starch, cellulose, pullulan, glucan and inulin, which do not contain functional groups other than the hydroxyl group, contrarily to chitosan, alginate or carrageenans [1]. They can either be linear, such as amylose, or ramified, such as amylopectin. These compounds are produced by animals, plants, algae, fungi and bacteria. 
Bacterial HoPS can be water soluble and produced in foods, especially fermented foods, in which they contribute to the functional properties. They belong to the family of exopolysaccharides (EPSs), which means that they are produced extracellularly. As such, their production has been mainly studied from lactic acid bacteria (LAB), but others, such as Bacillus, acetic acid bacteria, Streptomyces, Zymomonas, Pseudomonas or Paenibacillus, can produce HoPSs [1]. One particularity of bacterial HoPSs is that they can be produced at a high level, up to $70 \mathrm{~g} \mathrm{~L}^{-1}$ when conditions are optimized in Bacillus subtilis Natto [2,3].

Many studies investigated EPSs' bioactivites, and it is now recognized that EPSs exert anticancer, immunoregulatory (heteropolysaccharides), antidiabetic, antioxidant, anti-inflammatory, hypolipidemic and hypoglycemic effects (for a review see [1]). The observed effects change according to the producing strain and the subsequent nature of the produced EPS. As such, dextran obtained from the fermentation with Weissella spp. strains demonstrated antioxidant potential, just like heteropolysaccharides (HePS) from the same species $[4,5]$, and antifungal activity but no antibacterial activity against standard bacterial strains, as opposed to mannan produced from Weissella confusa, for example [6,7]. In addition, as dietary soluble fibers, some are investigated for prebiotic effect [8]. Apart from bioactivity, HoPSs are produced for industrial applications: cosmetics, tissue engineering, packaging or edible coating, agriculture as biosurfactants and petroleum industry [9]. In the food industry, they play a role in product texture and water retention. They have been extensively studied in dairy and bakery products and to a minor extent in beverages [10-13]. The long duration of fermentation is a positive factor that allows bacteria to produce EPS [14].

Naturally occurring polymers are receiving renewed attention as highly biocompatible and environmentally friendly materials. The HePS from LAB have long been characterized since they play an important role in the rheology, texture and "mouthfeel" of fermented milks and were studied for some other fermented products. HoPS have long been evaluated to a lesser extent; however, recently, the most notable advances in LAB-EPS research have been related to HoPSs as they could be considered as a promising alternative to conventional additives given their higher level of synthesis [15].

From an applied point of view, an improvement of food functional properties can be expected from HoPS production through inoculation of selected strains and process optimization. Hence, this review aims to draw a clear picture of the possibilities of modulation of EPS levels in fermented foods from the variability of bacterial sources and through the adjustment of environmental conditions.

\section{Variability in Structure and Size}

\subsection{Different Families of Homopolysaccharides}

HoPSs from bacteria are mainly formed from sucrose, by polymerization of either glucose or fructose. The enzymes involved belong to the hexosyltransferase family. The synthesis depends on the involved enzyme, which triggers the type of link between hexoses.

Four types of bacterial HoPSs (Figure 1) are described and divided into subclasses based on the type of linkage and the position of the carbon involved in the linkage: $\alpha$ glucans (dextran, alternan, reuteran and mutan), $\beta$-glucans, $\beta$-fructans (levan, inulin) and $\alpha$-galactans [16]. These four groups contain polysaccharides with different types of linkage, molecular weights or lengths and levels of ramification. 


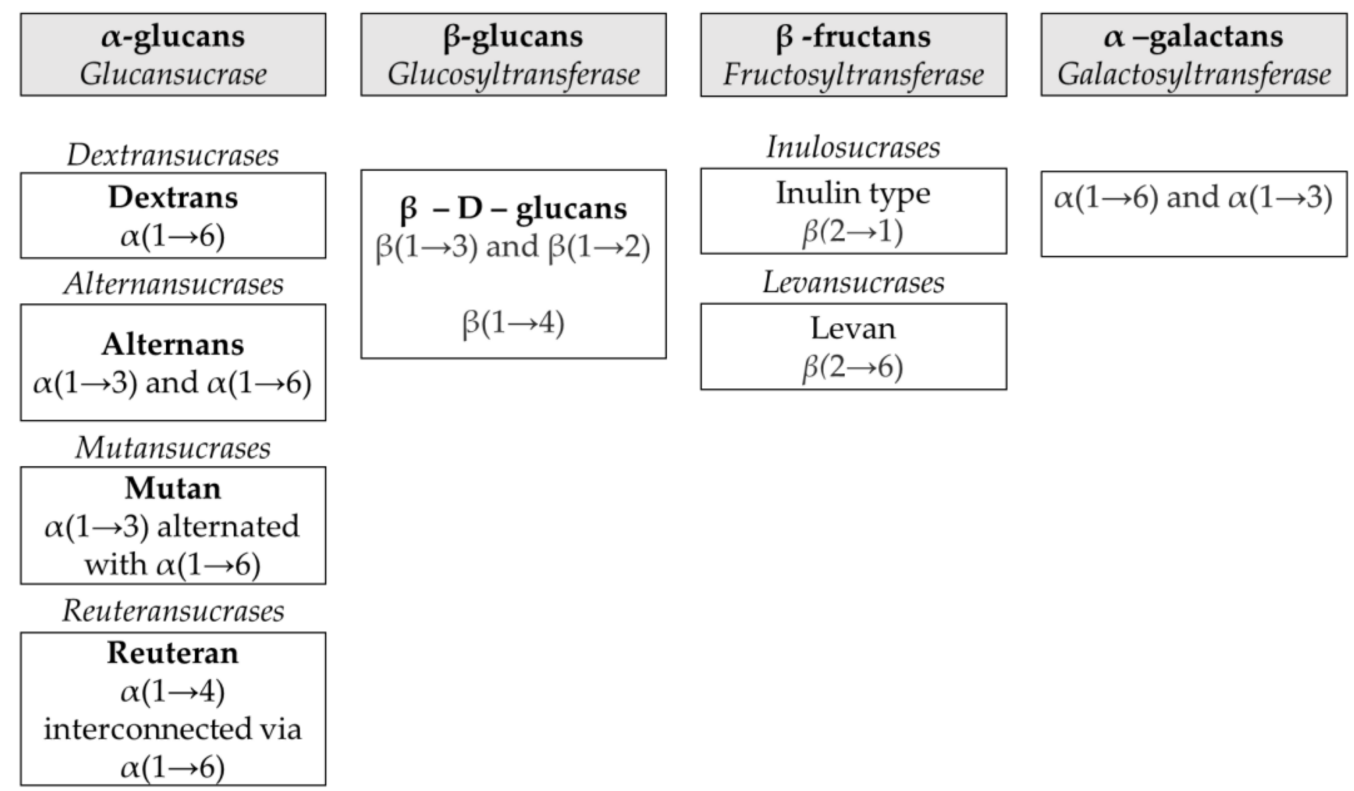

Figure 1. Classification of bacterial homopolysaccharides according to the enzymes involved and their linear chain linkages.

Generally, the molecular weights of HoPSs range from $4.0 \times 10^{4}$ to $1.8 \times 10^{9} \mathrm{Da}$. Some molecular weights are described for reuteran $\left(2.8 \times 10^{7} \mathrm{Da}\right)$, levan $\left(2.0 \times 10^{6} \mathrm{Da}\right)$ or inulin-like fructan $\left(1.0 \times 10^{7} \mathrm{Da}\right)[17,18]$. The size of dextrans varies between $10^{4} \mathrm{Da}$ for Acetobacter tropicalis to $10^{9} \mathrm{Da}$ for Oenococcus kitaharae $[19,20]$. The size of the EPS molecule may depend on the carbon source in the culture medium (Table 1). Polak-Berecka et al. [21] showed that the molecular weight of dextrans synthesized by Lactobacillus rhamnosus grown on five carbon sources, i.e., glucose, galactose, sucrose, maltose or lactose, were around $5.0 \times 10^{5}, 3.9 \times 10^{6}, 11.1 \times 10^{6}, 1.9 \times 10^{5}$ and $7.0 \times 10^{6} \mathrm{Da}$, respectively.

Table 1. Size and linkages according to the producing strain. HoPS: homopolysaccharide; Glc: glucose units; Fru: fructose units.

\begin{tabular}{|c|c|c|c|c|}
\hline Strain & HoPS & $\begin{array}{l}\text { Molecular Weight } \\
\text { Range (Da) }\end{array}$ & Linkage & Reference \\
\hline Leuconostoc mesenteroides TDS2-19 & Dextran & $9 \times 10^{7}$ & $\alpha(1 \rightarrow 6)$ Glc linear & [22] \\
\hline Leu. mesenteroides RTF10 & Dextran & $4 \times 10^{8}$ & $\alpha(1 \rightarrow 6)$ Glc and branched & [23] \\
\hline Latilactobacillus sakei MN1 & Dextran & $2 \times 10^{8}$ & $\begin{array}{c}\alpha(1 \rightarrow 6) \text { Glc and partially branched } \\
\text { in the } O-3 \text { position by a single } \\
\alpha \text {-glucopyranose unit (between } 8.5 \% \\
\text { and } 10.3 \%)\end{array}$ & [24] \\
\hline Leu. mesenteroides NRRL & Dextran & $6 \times 10^{5}$ & $95 \% \alpha(1 \rightarrow 6)$ Glc and $5 \% \alpha(1 \rightarrow 3)$ Glc & [16] \\
\hline Acetobacter tropicalis & Dextran & $1 \times 10^{4}$ to $4 \times 10^{4}$ & $\begin{array}{c}\alpha(1 \rightarrow 6) \text { Glc linear } \\
\alpha(1 \rightarrow 6) \text { Glc and 4,6-disubstituted }\end{array}$ & [19] \\
\hline Limosilactobacillus reuteri ML1 & Reuteran & & $\begin{array}{l}\alpha \text {-glucosyl units at the branching } \\
\text { points }\end{array}$ & [17] \\
\hline Levilactobacillus brevis TMW 1.2112 & $\beta$-Glucan & & $\begin{array}{c}\beta(1 \rightarrow 3) \text { Glc ramified with } \beta \text {-Glc } \\
\text { residues at position } O 2\end{array}$ & [25] \\
\hline Lim. reuteri 121 & Levan & $2 \times 10^{5}$ to $2 \times 10^{6}$ & $\begin{array}{c}98 \% \beta(2 \rightarrow 6) \text { Fru and } 2 \% \beta(1 \rightarrow 2) \\
\text { and } \beta(2 \rightarrow 6) \text { Fru branched }\end{array}$ & [18] \\
\hline Bacillus subtilis Natto & Levan & & $\beta(2 \rightarrow 6)$ fructofuranoside & [3] \\
\hline Lactobacillus rhamnosus & Inulin & $11 \times 10^{6}$ & $\begin{array}{l}\beta(2 \rightarrow 1) \text { Fru glycosidic and Fru } \\
\text { branched at the } \beta(2 \rightarrow 6) \text { position }\end{array}$ & [26] \\
\hline Lactobacillus gasseri DSM 20604 & Inulin & $6 \times 10^{6}$ & $\beta(2 \rightarrow 1)$ Fru glycosidic & [27] \\
\hline Weissella confusa KR780676 & Galactan & & $\alpha(1 \rightarrow 6)$ galactose & [28] \\
\hline
\end{tabular}




\section{2. $\alpha$-Glucans}

The $\alpha$-glucans are usually classified into four groups depending on the type of links and sequence in the HoPS: dextrans, alternans, reuterans and mutans.

Dextrans are mainly composed of a linear chain, e.g., 95\% in Leuconostoc mesenteroides or fully linear for $A$. tropicalis $[19,29]$. Dextrans can be linked by $\alpha(1 \rightarrow 6)$ glycosidic bonds and branched at the carbon atom at position 3 or, less frequently, at positions 2 and 4 [30]. Alternan contains in nearly equal proportion $\alpha(1 \rightarrow 3)$ and $\alpha(1 \rightarrow 6)$ linkages, which alternate on the chain with some degree of $\alpha(1 \rightarrow 3)$ branching.

Glucansucrases gather dextransucrase (EC 2.4.1.5) and alternansucrase (EC 2.4.1.140). The enzymes transfer a d-glucosyl residue from sucrose to a glucan chain and release dfructose. Those enzymes belong to the glycosyl hydrolase (GH) 70 family and descriptions can be found on the CAZy (Carbohydrate-Active Enzyme; www.cazy.org, accessed on 25 October 2021) and BRENDA (The Comprehensive Enzyme Information System; www. brenda-enzymes.org, accessed on 25 October 2021) databases. Until 2016, GH70 enzymes were only described in lactic acid bacteria (LAB) [31].

Dextransucrase is largely described in Leu. mesenteroides and in others LAB such as Latilactobacillus curvatus, Leuconostoc citreum, Leuconostoc lactis, Limosilactobacillus reuteri, Liquorilactobacillus hordei, O. kitaharae, Pediococcus pentosaceus, Weissella cibaria and W. confusa. A. tropicalis and Streptococcus mutans also produce a dextransucrase [19]. It mainly catalyzes the formation of $\alpha(1 \rightarrow 6)$ linkages, plus possibly side-chains linked with $\alpha(1 \rightarrow 2), \alpha(1 \rightarrow 3)$ or $\alpha(1 \rightarrow 4)$ linkages. The size and structure of dextrans are mainly affected by the sequence and structure of dextransucrase. Mutagenesis has shown dextransucrase regions involved in dextran size and other amino acids of the protein sequence implied in branching [32,33].

Alternansucrase is produced by Leu. mesenteroides and Leu. citreum. As for dextransucrase, the role of certain amino acids of the enzyme is of high importance regarding the size of the polysaccharide and the type of linkages. For instance, mutation of L940 increases the percentage of $\alpha(1 \rightarrow 6)$ linkages and L940W leads to absence of linkages of the $\alpha(1 \rightarrow 3)$ type and more oligo- than polysaccharides [34]. Similarly the nature of amino acids involved in acceptor sub-sites was shown to modify the linkage type [35].

Reuteransucrase, responsible for reuteran synthesis, differs from dextransucrase as it produces a HoPS containing mainly $\alpha(1 \rightarrow 4)$ linkages, interconnected via $\alpha(1 \rightarrow 6)$ bridges [17]. Slight differences in the sequence, as weak as a triple amino acid mutation, can lead to differences of HoPS structure from $70 \% \alpha(1 \rightarrow 4)$ linkages to $80 \% \alpha(1 \rightarrow 6)$ linkages [17]. Reuteransucrases are produced by Lim. reuteri [36], for instance, the reuteran from the probiotic bacterium Lim. reuteri 121 contains $\alpha(1 \rightarrow 4)$ and $\alpha(1 \rightarrow 6)$ glycosidic linkages in proportions of $58 \%$ and $42 \%$, respectively [36].

Mutans are polymers consisting of glucose residues containing more than $50 \%$ of $\alpha(1 \rightarrow 3)$ glucoside linkages, mainly associated with $\alpha(1 \rightarrow 6)$ linkages. They are produced by Lim. reuteri, Leu. mesenteroides and several strains of Streptococcus [30].

The properties of dextran, regarding rheology, depend on its structure and size. The shorter the linear chain, the lower the viscosity $[19,20]$. Other factors, such as $\mathrm{pH}$, the presence of maltose or temperature, play a role in the structure and size of the produced HoPS dextran [37-39].

\section{3. $\beta$-Glucans}

Most $\beta$-glucans from bacterial origin are unbranched glucose polymers linked via $\beta(1 \rightarrow 3)$ glycosidic bonds. In some cases, trisaccharide repeats linked by $\beta(1 \rightarrow 3)$ form a linear chain, and ramifications are formed from $\beta(1 \rightarrow 2)$ glucose units. They are produced by Levilactobacillus brevis, Pediococcus claussenii [40], Pediococcus parvulus, Oenococcus oeni [41] and other Pediococcus or Lactobacillus species [42,43]. The enzyme is a 1,3- $\beta$-glucan synthase (EC 2.4.1.34), which uses intracellular UDP-glucose as a substrate.

In addition, acetic acid bacteria, such as Acetobacter and Gluconobacter, produce longchains of $\beta(1 \rightarrow 4)$ glucan, called bacterial cellulose, and adopt a ribbon-like secondary structure [44]. 
Viscosity of $\beta$-glucans is directly related to their molecular weight, molecular structure, solubility in water and food matrix [45]. The impact of the linkage type on the litheness of the polysaccharidic chain is recognized: $\beta(1 \rightarrow 4)$ bonds result in stiffer chains compared to $\alpha(1 \rightarrow 4)$ or $\beta(1 \rightarrow 3)$ bonds [46].

\subsection{Fructans}

Inulin is composed of branched $\beta(2 \rightarrow 1)$ fructose linkages whereas levan has $\beta(2 \rightarrow 6)$ or $\alpha(2 \rightarrow 1)$ and $\alpha(2 \rightarrow 6)$ fructose linkages.

Bacterial inulin is obtained from inulosucrase (EC 2.4.1.9) activity. It catalyzes the transfer of a fructose residue from sucrose to form a polysaccharide chain connected by $\beta(2 \rightarrow 1)$ fructosyl linkages, resulting in the synthesis of high-molecular-weight inulin polymers. Inulosucrase is found in Bacillus sp., Leu. citreum, Lactobacillus johnsonii, Lactobacillus gasseri, Lim. reuteri, Paenibacilllus macerans, W. confusa and W. cibaria [27].

Levansucrase (EC 2.4.4.10) catalyzes the transfer of D-fructosyl residues from fructose to yield $\beta(2 \rightarrow 6)$ osidic bonds, which characterize levan. Many bacteria produce this enzyme, such as Bacillus licheniformis, B. subtilis, Fructolactibacillus sanfranciensis, Gluconoacetobacter sp., Gluconobacter oxydans, L. gasseri, Leu. mesenteroides, Lim. reuteri, Paenibacillus polymyxa, Pseudomonas spp. and Zymomonas mobilis. L. reuteri 121 is known to produce a linear levan [47]. Leu. mesenteroides NRRL B-512F produces levansucrase in addition to dextransucrase. Levansucrase is responsible for at least $25 \%$ of the reducing sugars released when grown in the presence of sucrose. This corresponds to a significant level of glucose and explains why fructose repression of dextransucrase is observed in Leu. mesenteroides [48].

\section{5. $\alpha$-Galactans}

Galactans are a relatively less abundant class of polysaccharides, and their main structure is characterized by a chain of galactose units linked by $\alpha(1 \rightarrow 6)$ and $\alpha(1 \rightarrow 3)$ bridges [49]. W. confusa KR780676 produces a linear galactan containing $\alpha-(1 \rightarrow 6)$-linked galactose units [28].

\section{Gene Regulation and Variability of HoPS Production Level}

The bacterial genes responsible for EPS production and the promotion of various secondary functional features to the bacteria have been explored. Studies helped to specifically identify the genes that are crucial in the production process of bacterial HoPSs. Depending on their great structural diversity, EPSs can be produced by microorganisms via different pathways. HoPSs are unique in that they are synthesized by extracellular glycansaccharides using mostly sucrose as the glycosyl donor (fructose or glucose). Described in the genera Weissella, Leuconostoc, Lactobacillus and Pediococcus, the synthesis pathway of HoPSs generally occurs extracellularly [50]. HoPSs are produced by transglycosylases (glycansucrases), which are able to use the energy of the osidic bond of sucrose to catalyze the transfer of a corresponding glycosylated fraction. The transfer of monosaccharide in a specific substrate (e.g., sucrose) to the medium results in the growth of polysaccharide chains [51]. Most of the HoPS producing-LAB harbor only one glucansucrase gene; however, some LAB genomes exhibit more than one gene encoding hexosyltransferases and are, thus, able to synthesize different HoPSs. For instance, the Leu. mesenteroides NRRL B-512F strain coding both a glucansucrase and a fructansucrase can produce levan in addition to the dextran usually produced [52].

The subsequent production of HoPSs by LAB can be regulated by the production level and the activity of these enzymes. Of note, the production of dextransucrase is dependent on the presence of sucrose for all species, except some Streptococcus spp. On the contrary, reuteransucrase is constitutively expressed whatever the sugar [53]. The optimum sucrose level varies depending on the strain, generally between $2 \%$ and $5 \%$ for dextransucrase but up to $10 \%$ for reuteransucrase. On the other hand, $\mathrm{pH}$ of the medium does not influence 
the level of production of the enzyme but could act on its stability [37]. Divalent cations, $\mathrm{Ca}^{2+}, \mathrm{Mg}^{2+}$ and $\mathrm{Mn}^{2+}$ and dextrans activate and stabilize the enzyme of Leu. mesenteroides.

The production of EPSs can be influenced by changing the nature or quantity of substrates or available nutrients as well as by changing the $\mathrm{pH}$, water activity, temperature and oxygen concentration of the culture medium [36]. The structure of the EPSs and their content vary according to the sources of carbon, nitrogen, phosphorus or sulfur. Sucrose is the most commonly used substrate for the synthesis of HoPSs and often the best substrate for HoPS production yield. $\mathrm{LAB}$ are sensitive to $\mathrm{pH}$ and the nature and amount of sugars. These factors must be taken into consideration for the production of EPSs in fruit and vegetable products with respect to their composition [52]. The specificity of carbon substrate differs from species to species. The temperature and yield depend on the different strains used (Table 2).

Regulation at constant $\mathrm{pH}$ favors better HoPS yields, because glycohydrolases are activated when acidification occurs due to lactate production, around $\mathrm{pH} 5$. When the maximum concentration of lactate is reached in L. rhamnosus culture, the polysaccharide yields decrease due to enzymatic digestion. It usually corresponds to 24 to $48 \mathrm{~h}$ of fermentation [21]. The study by Polak-Berecka et al. [26] showed that culture conditions have a strong effect on the production of EPSs by L. rhamnosus and scaling from flask to fermenter can increase EPS biosynthesis by $175.8 \%$ in commercial production processes.

The viscosity of aqueous solutions is partly linked to HoPS level, molecular weight, degree of chain stiffness, radius of gyration of the molecule and the presence of ionizable groups that confer polyelectrolytic behavior to the polymer [54]. Looijesteijn et al. [55] reported that the main factor in the viscosity intensifying ability of EPS was the molecular weight. In this study, Lactococcus lactis subsp. cremoris strains NIZO B40 and NIZO B891 produced EPS with lower molecular weight in a medium with a low glucose content. The chemical composition of these polymers remained unchanged, but the rheological properties of the solution changed.

Table 2. Influence of culture conditions and strains on HoPS production yield.

\begin{tabular}{|c|c|c|c|c|c|c|c|}
\hline Strain & MW (Da) & $\begin{array}{c}\text { Optimum } \\
\text { Temperature } \\
\left({ }^{\circ} \mathrm{C}\right)\end{array}$ & $\mathrm{pH}$ & $\begin{array}{l}\text { Medium } \\
\text { Composition }\end{array}$ & $\begin{array}{l}\text { Yield } \\
\left(\mathrm{g} \mathrm{L}^{-1}\right)\end{array}$ & Application & Reference \\
\hline $\begin{array}{l}\text { Leu. mesenteroides } \\
\text { TDS2-19 }\end{array}$ & $8.8 \times 10^{7}$ & 25 & 6.8 & MRS $^{1}$ medium & 71.23 & $\begin{array}{l}\text { Used in food industries as } \\
\text { an emulsifier or as part of } \\
\text { starter culture }\end{array}$ & [22] \\
\hline $\begin{array}{l}\text { Leu. mesenteroides } \\
\text { RTF10 }\end{array}$ & $4.4 \times 10^{8}$ & 30 & 4.8 & $\begin{array}{l}\mathrm{CDM}^{2} 0.8 \% \\
\text { sucrose }\end{array}$ & 1.25 & $\begin{array}{c}\text { Used as adjuvant and } \\
\text { stabilizer in food industries }\end{array}$ & [23] \\
\hline Lat. sakei MN1 & $1.7 \times 10^{8}$ & 30 & & MRS $2 \%$ sucrose & 1.72 & Used for biofilm formation & [24] \\
\hline W. cibaria MG1 & $7.2 \times 10^{8}$ & 30 & $4.0-4.1$ & MRS $10 \%$ sucrose & & $\begin{array}{l}\text { Used in bakery for sorghum } \\
\text { bread }\end{array}$ & [7] \\
\hline Lim. reuteri ML1 & & 35 & 4.7 & $\begin{array}{l}\text { Sucrose (purified } \\
\text { enzyme) }\end{array}$ & 5.12 & & [17] \\
\hline Lim. reuteri 121 & & 37 & 4.8 & $\begin{array}{l}\text { MRS medium } \\
\text { sucrose }\end{array}$ & 5.2 & & [56] \\
\hline Lim. reuteri VIP & $1.0 \times 10^{7}$ & 37 & 3.6 & MRS $10 \%$ sucrose & & $\begin{array}{l}\text { Used in bakery for } \\
\text { sorghum bread }\end{array}$ & [7] \\
\hline B. subtilis Natto & & 37 & $5.6-5.8$ & $\mathrm{SM}^{3}$ sucrose $20 \%$ & 70.60 & $\begin{array}{l}\text { Used in pharmaceutical } \\
\text { industries as a commercial } \\
\text { spore, on alginate matrix for } \\
\text { repeated production of levan }\end{array}$ & [3] \\
\hline $\begin{array}{l}\text { Weissella hellenica } \\
\text { SKkimchi3 }\end{array}$ & $20.3 \times 10^{4}$ & 20 & 5 & MRS sucrose $30 \%$ & 74.00 & & [2] \\
\hline Lim. reuteri 121 & $2.0 \times 10^{6}$ & 37 & $4.5-5.5$ & In vitro enzyme & & & [18] \\
\hline L. rhamnosus & $11.1 \times 10^{6}$ & 37 & 5.0 & $\mathrm{YNB}^{4}$ & 2.10 & & [26] \\
\hline Lim. reuteri $\mathrm{Y} 2$ & $8.9 \times 10^{6}$ & 37 & $3.7-3.8$ & $\begin{array}{l}\text { MRS } 2.5 \% \text { sucrose } \\
\quad \text { or raffinose }\end{array}$ & & & [7] \\
\hline $\begin{array}{l}\text { L. gasseri DSM } \\
20604\end{array}$ & $5.8 \times 10^{6}$ & 35 & 5.5 & sucrose & 53.00 & & [27] \\
\hline
\end{tabular}

${ }^{1}$ MRS is composed of sucrose, yeast extract, beef extract, anhydrous sodium acetate, ammonium citrate ${ }^{2} \mathrm{CDM}$, chemically defined medium; ${ }^{3} \mathrm{SM}$, Spizizen medium; ${ }^{4} \mathrm{YNB}$, yeast nitrogen base. 


\section{Effect of Food Composition and Processing}

In the case of EPS synthesis occurring during food processing, the production yield will be influenced by the food environment on top of the experimental conditions of fermentation (Figure 2).

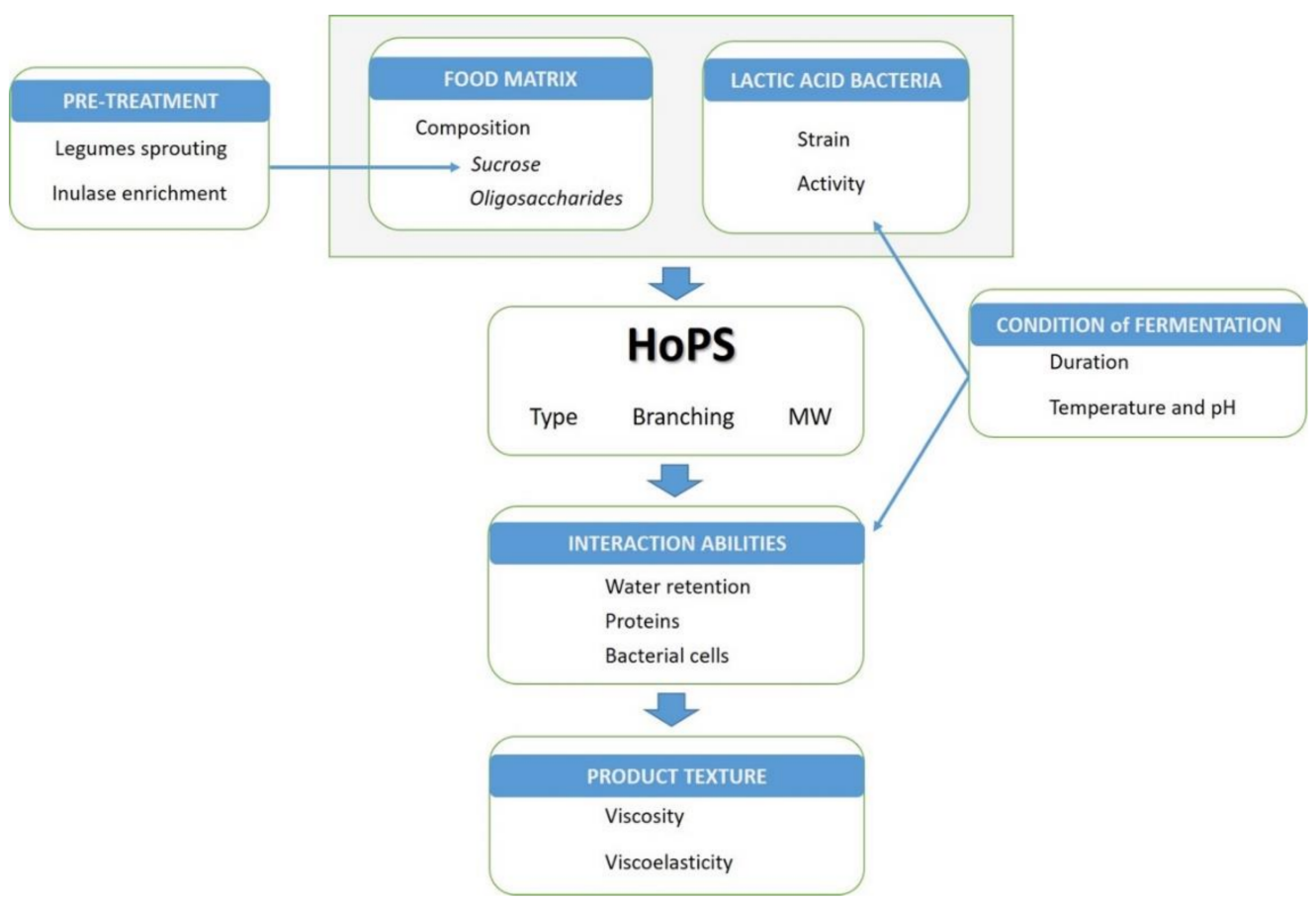

Figure 2. Relation between food matrix, processing parameters and product technological parameters.

\subsection{Role of the Matrix Composition}

The importance of the choice of the substrate was shown for HoPS production in cereals, influencing both the level of production or the structure of the HoPS [57]. Thereby, during sourdough production based on four different flours (buckwheat, quinoa, sorghum and teff) with a dextran-producing $W$. cibaria strain, EPS and oligosaccharide concentrations were observed to be inversely related. The highest dextran content was formed in sourdoughs prepared with buckwheat (4.2 $\mathrm{g} \mathrm{EPS} \mathrm{kg}^{-1}$ sourdough) and quinoa (3.2 $\mathrm{g}$ EPS $\mathrm{g}^{-1}$ sourdough). Furthermore, the level of maltose in flour was found to be a key point for high-molecular-weight EPS synthesis. Maltose was found to be higher in wheat and lowest in buckwheat, resulting in the lowest levels of high-MW dextran in wheat sourdoughs [57,58].

Factors such as monosaccharide composition, type of linkage, side chains, molecular weight and their interaction with other constituents (mainly casein and ions) also affect the rheological functions of EPS lactobacilli in fermented milk products [59].

\subsection{Addition of Ingredients}

It is known that sucrose is first used by LAB for growth during the exponential phase and then can be used for dextran production during the stationary phase by EPS-producing strains liberating fructose. Sucrose addition was tested on fava bean flour fermented with Leuconostoc spp. and Weissella spp. to evaluate it potential in EPS production [60]. It was observed that the addition of sucrose strongly induced dextran and glucan production when compared to control fava bean dough fermented with the same starter. Glucan contents were found to be higher than dextran contents in all cases, with $1.86 \%$ to $3.67 \%$ and $2.57 \%$ to $4.33 \%$ in sucrose-enriched doughs versus $0.32 \%$ to $0.82 \%$ and $0.11 \%$ to $0.74 \%$ in control dough, respectively, as low- and high-branched dextrans were both included in glucans. Interestingly, the higher production of glucan noticed for Leuconostoc spp. compared to 
Weissella spp. in sucrose-enriched doughs could be related to the low-branched dextran preferentially produced by Weissella spp. while Leuconostoc spp. tend to produce more than one type of dextran.

Sucrose addition was also tested on legume-based sourdough as a potential approach to improve the use of legume flour in bakery products. The addition of $2 \%$ of sucrose during fermentation at a temperature of $30^{\circ} \mathrm{C}$ allowed the production of linear dextran with $2.6 \%$ $\alpha(1 \rightarrow 3)$ linked branches by a $W$. confusa strain isolated from spontaneous fermentation and promoted the technological properties of legume-based sourdough [61].

Strategies to promote sugar availability in tubers also include enzyme activity, e.g., inulinase was added in Jerusalem artichoke for simultaneous saccharification and fermentation with Bacillus velezensis LT-2. The maximum EPS yield $\left(9.25 \mathrm{~g} \mathrm{~L}^{-1}\right)$, benefiting from a shortened fermentation period by $26.67 \%$ and a significantly associated reduced cost, was obtained with the inulinase dosage of $18 \mathrm{U} \mathrm{g}^{-1}$ sugar. This condition provided sufficient monosaccharides while exhibiting no substrate inhibition and affected the bacterial genes ${ }^{\prime}$ regulation in the following aspects: impaired fructose inhibition, accelerated the synthesis of EPS nucleotide-sugars precursors, induced the transcription of the EPS synthetic gene cluster and strengthened the electron transport respiratory chain and transporter system [62].

The influence of fat content on EPS production was tested in meat fermented products with the aim of producing fat-reduced sausages. For a final fat content ranging between $17 \%$ and $33 \%$, the EPS production observed in spreadable raw sausages ranged between 0.46 and $1.03 \mathrm{~g} \mathrm{~kg}^{-1}$ for the HoPS-producing strains Latilactobacillus sakei 1.411 and Lat. curvatus, 1.1928 resulting in reduced hardness and higher softness. However, no significant differences of HoPS production levels were noted for the different fat contents [63].

\subsection{Pretreatments}

Some pretreatments are considered to modulate the level of EPS production in the food matrix. This is the case with sprouting, which was recently tested for lentil flour [64]. The dextran levels synthesized in situ by a W. confusa strain were found to be slightly higher in sprouted lentil sourdoughs than in those with unsprouted lentils, with $9.7 \%$ and $9.2 \%$ $\mathrm{w} / \mathrm{w}$ flour weight, respectively.

It appears that other pretreatments influence the EPS production yield as is the case for thermal treatment. The heat intensity applied upstream of fermentation seems to be a determining factor, as demonstrated in a lupin-based milk alternative, where a more intensive heat treatment (ultra-high temperature) resulted in higher amounts of HePSs and better rheological and textural properties than pasteurization [65].

Nonthermal technology such as ultrasound was also used to shorten fermented products' fermentation time. This technology allows to shorten the adaptation phase of microorganisms in the growth curve and enhance the membrane permeability, therefore allowing a mass transfer. This technic showed a tendency to improve the EPS production rate in kefir [66].

\subsection{Conditions of Fermentation}

The role of fermentation conditions on in situ EPS production levels was shown on sucuk sausage, the most consumed fermented meat product in Turkey [67]. A similar tendency for the EPS production levels with both Latilactobacillus plantarum and Leu. mesenteroides strains was observed when fermentation temperatures of 14 to $18{ }^{\circ} \mathrm{C}$ and durations of 8 to 16 days were compared. The EPS production increased significantly with the prolongation of ripening period and fermentation temperature, from 4.68 to $18.96 \mathrm{mg}$ EPS $\mathrm{kg}^{-1}$ dry matter, in a conversely proportional way to $\mathrm{pH}$. This can be related with the temperature requirement and growth-associated dependency of EPS production depending on the mesophilic or thermophilic nature of the strain. 


\subsection{Traditional (Spontaneous) vs. Inoculated}

Lactic acid bacteria EPSs from spontaneously fermented wheat bran sourdough have been studied under the prism of the production by dominant isolates $[68,69]$. However, the diversity or the level of EPS production in spontaneous fermented food in comparison with inoculated fermented food has not been characterized, and the question remains of interest for functional food optimization.

\section{Technological Impact of EPSs in Foods, Depending on Matrix and Processing Conditions}

The combination of the endogenous factors of the matrix and the exogenous factors relative to the applied processes greatly influences the synthesis and the properties of EPSs in foods and, ultimately, the quality of the final product (Table 3).

Table 3. Influence of some food pretreatment and processing condition on EPS production and properties.

\begin{tabular}{|c|c|c|c|c|}
\hline EPS & Strain & Processing Conditions & Effects & Reference \\
\hline Dextran & W. cibaria MG1 & $\begin{array}{l}\text { Different fermented flours } \\
\text { (buckwheat, quinoa, } \\
\text { sorghum and teff) used as } \\
\text { the basis for bread recipes } \\
\text { using sourdough }\end{array}$ & $\begin{array}{l}\text { Yield depended on the substrate and was highest in } \\
\text { buckwheat and quinoa sourdough. The level of } \\
\text { maltose in flour influences the MW of synthetized } \\
\text { EPSs in sourdoughs (lower maltose in buckwheat } \\
\text { resulting in the most high-MW dextran). } \\
\text { Bread rheological properties were influenced by the } \\
\text { flour matrix in relation to the variability of HoPS: } \\
\text { reduction of crumb hardness in buckwheat } \\
\text { (-122\%), teff and quinoa breads; reduction of the } \\
\text { staling rate in buckwheat and teff breads. }\end{array}$ & [57] \\
\hline Dextran & $\begin{array}{l}\text { W. confusa VTT } \\
\text { E-90392 }\end{array}$ & $\begin{array}{l}\text { In situ EPS production in } \\
\text { wheat sourdoughs, } 10 \% \\
\text { enriched with sucrose or } \\
\text { unenriched. Sourdoughs } \\
\text { were used in baking at } 43 \% \\
\text { of the dough weight. }\end{array}$ & $\begin{array}{l}\text { W. confusa efficiently produced polymeric dextran } \\
\text { (11-16 g/kg DW) from the added sucrose in wheat } \\
\text { sourdough without strong acid production. } \\
\text { The produced dextran significantly increased the } \\
\text { viscosity of the sourdoughs. Application of } \\
\text { dextran-enriched sourdoughs in bread baking } \\
\text { provided mildly acidic wheat bread with improved } \\
\text { volume (up to } 10 \% \text { ) and crumb softness ( } 25-40 \%) \\
\text { during } 6 \text { days of storage. }\end{array}$ & [70] \\
\hline Dextran & W. confusa SLA4 & Lentil flour sprouting & $\begin{array}{l}\text { Increase slightly the dextran synthesis in } \\
\text { comparison to nonsprouted lentil sourdoughs ( } 9.7 \% \\
\text { and } 9.2 \% \mathrm{w} / \mathrm{w} \text { flour weight, respectively). }\end{array}$ & {$[64]$} \\
\hline EPS & Kefir starter culture & Ultrasonic sound waves & $\begin{array}{c}\text { The treatment allows kefir production in a shorter } \\
\text { time by affecting the growth rate and lactic acid } \\
\text { and EPS production rate. }\end{array}$ & [66] \\
\hline EPS & $\begin{array}{c}\text { Latilactobacillus } \\
\text { plantarum } 162 \mathrm{R} \text { and } \\
\text { Leu. mesenteroides N6 }\end{array}$ & $\begin{array}{l}\text { Ripening period and } \\
\text { fermentation temperature }\end{array}$ & $\begin{array}{c}\text { Increase of EPS production level, associated with } \\
\text { hardness reduction of the fat-reduced products and } \\
\text { lower loss and storage moduli, when the ripening } \\
\text { period was prolonged and the fermentation } \\
\text { temperature was higher. }\end{array}$ & [67] \\
\hline $\begin{array}{l}\text { Dextran } \\
\text { Fructan, glucan } \\
\text { Dextran }\end{array}$ & $\begin{array}{c}\text { Latilactobacillus } \\
\text { curvatus TMW } 1.624 \\
\text { Ligiactobacillus animalis } \\
\text { TMW } 1.971 \\
\text { Lim. reuteri TMW } \\
1.106\end{array}$ & $\begin{array}{l}\text { In situ production of various } \\
\text { EPSs compared to the } \\
\text { addition of hydroxypropyl- } \\
\text { methylcellulose } \\
\text { (HPMC) }\end{array}$ & $\begin{array}{l}\text { Only HPMC and the dextran of Lat. curvatus TMW } \\
\text { 1.624 retained water. The moisture content, baking } \\
\text { loss and crumb firmness were improved the most } \\
\text { by dextran of Lat. curvatus TMW } 1.624 \text {. } \\
\text { Structure analysis revealed that this dextran had } \\
\text { the highest molecular weight of the analyzed EPSs } \\
\text { (118-242 MDa) and was branched in position } 3 \\
\text { (8-9\%). A structure-function relation was } \\
\text { suggested in which high weight, average molar } \\
\text { mass and branching at position } 3 \text { of the glucose } \\
\text { monomer foster a compact conformation of the } \\
\text { molecule, enabling an increased water-binding } \\
\text { capacity and promoting superior structural effects } \\
\text { in gluten-free breads. }\end{array}$ & [71] \\
\hline
\end{tabular}


Table 3. Cont.

\begin{tabular}{|c|c|c|c|c|}
\hline EPS & Strain & Processing Conditions & Effects & Reference \\
\hline Dextran & $\begin{array}{c}\text { Leuconostoc } \\
\text { pseudomesenteroides } \\
\text { DSM } 20193 \text { and } W . \\
\text { confusa E3403 }\end{array}$ & $\begin{array}{l}\text { In situ production in legume } \\
\text { protein-rich foods (fava bean } \\
\text { protein concentrate) }\end{array}$ & $\begin{array}{l}\text { Stabilization, prevention of protein aggregation. } \\
\text { Improvement in rheological and textural } \\
\text { parameters in sucrose-added pastes after } \\
\text { fermentation. W. confusa exhibited a higher } \\
\text { viscosity index and a more rigid character of } \\
\text { formed gel values than Leu. pseudomesenteroides } \\
\text { (1441 and } 766 \text { g sof viscosity index, } 0.39 \text { and } 0.23 \text { of } \\
\text { relative viscoelasticity index tan } \delta \text {, respectively). }\end{array}$ & [72] \\
\hline Dextran & $\begin{array}{l}\text { W. confusa DSM 20194, } \\
\text { compared to probiotic } \\
\text { strains (Lat. plantarum } \\
\text { T6B10, L. rhamnosus } \\
\text { SP1) }\end{array}$ & $\begin{array}{l}\text { Quinoa flour subjected to } \\
\text { desaponification and } \\
\text { gelatinization prior to } \\
\text { fermentation }\end{array}$ & $\begin{array}{l}\text { The content of } 35 \%, \mathrm{w} / \mathrm{w} \text { of quinoa flour in water } \\
\text { was determined as optimal regarding the viscosity } \\
\text { parameter. The viscosity and water holding } \\
\text { capacity increased during fermentation with } W \text {. } \\
\text { confusa, as the consequence of the EPS synthesized, } \\
\text { contrary to what observed for other strains ( } 0.7 \mathrm{~Pa} \text { s } \\
\text { and } 98 \% \text { observed for } W \text {. confusa versus } 0.2 \mathrm{~Pa} \text { s and } \\
69-70 \% \text { for the other tested strains, respectively). }\end{array}$ & [73] \\
\hline
\end{tabular}

\subsection{Applications of EPSs}

There are many potential industrial applications for LAB-originated EPSs based on their role as gelling, thickening, emulsifying, stabilizing, water-binding and viscosifying agents. EPS technological features are traditionally useful in fermented dairy foods manufacture such as yogurt, milk-based desserts, kefir, cultured cream or cheese. They can act as thickeners and texturizers conferring advantageous properties during the process. Their structure allows them to bind water to stabilize and increase the viscosity of the final product, to interact with milk proteins and micelles to improve the firmness of the casein network and at the same time to decrease syneresis [74].

HePSs, composed of several carbohydrate moieties, play an important role in dairy products as they can be produced from various sugars and notably lactose in the absence of sucrose $[75,76]$. It was shown that HePSs produced by utilizing different carbon sources vary only in the fraction of different sugars, while the composition remained the same, indicating that sugar type has no effect on the composition of HePSs despite its capacity to process the sugars into various monomer units [77].

HoPSs on the other hand, consisting mainly of glucose or fructose, are effectively used in cereal- and legume-flour-based products as a natural alternative to commercial hydrocolloids for the enhancement of both gluten-containing and gluten-free cereal- and legume-based products [71]. The exploitation of HoPS production is also particularly interesting in yogurt-like beverages or cheese alternatives aiming to mimic fermented dairy products, because the polysaccharides formed improve the textural and sensory properties and extend the shelf life of these plant-based products [74].

\subsection{In Situ Production versus Ex Situ Addition}

LAB-derived EPSs can be added as additives in foods or formed in situ. EPSs can be considered for addition into food products during processing as a biopolymer, as an alternative that is easier to control than in situ production by LAB culture. The addition of adapted amounts of polysaccharide at a specific time-point during food processing can lead to the desired functional and physical characteristics of the end product. This use of dextran is currently allowed by the European Commission at levels of up to $5 \%$ in bakery products [78] provided it is listed as an additive in the ingredients on packaging. For instance, the ex situ production and the use of bacterial EPSs as ingredients enables wider application of this category of EPSs since, in this form, the polymer can be added to the food in greater quantities than it would be if synthetized in situ [79].

Regarding the ex situ addition, hydrocolloids such as xanthan or hydroxypropylmethylcellulose are commonly used in gluten-free formulations in order to improve the viscoelastic properties of doughs. Indeed, gluten-free products are characterized by low water absorption, changes in crumb characteristics, decreased bread volume and poor 
stability. The efficiency of in situ HoPS production on the structure and quality of glutenfree bread enhancement has been studied by comparing buckwheat and rice flour mix and supplemented with different Lactobacillus EPSs (levan and dextran) or hydroxypropylmethylcellulose by Rühmkorf et al. [71]. In this study, all supplements increased the specific volume and reduced the crumb hardness noticeably. However, the improvement in moisture content, baking loss and crumb hardness were higher with dextran produced by the L. curvatus TMW 1.624 strain. This specific dextran was found to have a higher water retention capacity and molar mass than other analyzed EPSs. A structure-function relation was suggested in which high weight, average molar mass and branching at position 3 of the glucose monomer foster a compact conformation of the molecule and higher water binding capacity, conferring a high efficiency to this in situ HoPS. It goes in the direction of more efficiency for EPSs formed in situ compared to that of those produced ex situ and then added externally, as previously reported for bread [80]. In addition, the in situ production of EPS is generally considered as a promising alternative to conventional additives [75]. In situ production of EPS by EPS-producing strains present many advantages since it has less impact on production cost than addition, isolation and purification of EPS for use as an ingredient, and it fits the consumer demand for products with fewer additives and "clean labeled" products.

\subsection{Texture}

Independently of their origin, EPSs have been classified based on their functionality. It has been established that the intrinsic properties of EPSs (e.g., composition, branching, charge, molar mass) drive inter-macromolecular associations through hydrogen bonds, electrostatic or ionic forces. These factors are a key point for protein interaction and complexations with bacterial cells that are of great importance in rheological properties of fermented products, pro- and prebiotics interactions and biofilm formation [81]. Based on this statement, a web-based platform-independent database of bacterial exopolysaccharides provides access to detailed structural. Taxonomic, growth conditions, functional properties and genetic and bibliographic information for EPS (http:/ / www.epsdatabase.com) (accessed on 21 December 2021) in order to provide a fast access to functional EPS properties.

\subsubsection{Rheological Properties}

The comparison of bread recipes using sourdough obtained from different fermented flours (buckwheat, quinoa, sorghum and teff) with a dextran-producing $W$. cibaria strain has shown an impact of the flour matrix on the bread's rheological properties. For instance, the crumb hardness was reduced in buckwheat $(-122 \%)$, teff and quinoa breads whereas a significant reduction of the staling rate was observed in buckwheat and teff breads in relation with the variability of HoPS production [57].

\subsubsection{Viscosity}

Specific spatial properties of the macromolecular conformation of EPSs are reflected in the intrinsic viscosity value [ $\eta$ ]. This hydrodynamic parameter is influenced by the chain length, the backbone stiffness, the charge and the molecular weight and can be considered a key parameter describing the thickening capacity of a polysaccharide. Intrinsic viscosity depends on polymer size and conformation as well as on polymer-solvent interactions. As

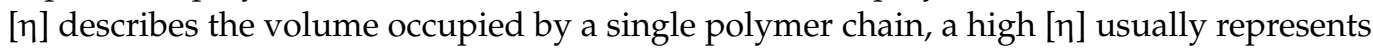
large molecules and stiff chains, whereas low $[\eta]$ indicates small molecules and flexible chains [82]. In solution, HoPSs have generally low [ $\eta$ ]. As such, levans have a very low

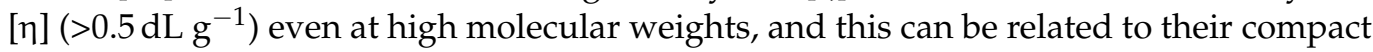

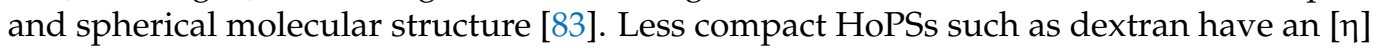
between 0.1 and $1.5 \mathrm{dL} \mathrm{g}^{-1}$ [84,85]. By comparison, polyionic EPSs such as xanthan have a more extended structure due to their charge repulsion and a greater [ $\eta$ ( up to $76 \mathrm{dL} \mathrm{g}^{-1}$ ) as ordered secondary structure can also affects [ $\eta]$ [86]. 
The impact of in situ produced EPS on acidification, rheology and texture was evaluated in legume protein-rich foods by comparing two strains of Leuconostoc pseudomesenteroides and $W$. confusa. Along with a higher amount of dextran, a clear improvement in rheological and textural parameters was observed in $5 \%$ sucrose-added fava bean pastes after fermentation [72]. Higher viscosity index and viscoelasticity values (firmness, consistency, cohesiveness) were observed, conferring an elastic-paste structure due to the presence of dextran that could interact with proteins and further strengthen the gel structure, compared to pastes fermented with the same starter having a liquid structure. The benefit of in situ dextran production in fava bean protein is emphasized, since the observed properties could not be mimicked by simply mixing dextran, organic acids and the protein concentrate.

Several studies following the effect of sucrose supplementation in sterile skim milk textural properties demonstrated that milk solidification depended on the concentration of sucrose added with EPSs produced by Weissella sp. TN610, W. hellenica SKkimchi3 and Leu. pseudomesenteroides PC strain from pickled Chinese cabbage $[2,87,88]$. In the case of EPS from Leu. pseudomesenteroides, good pseudoplastic rheological properties and an increased viscosity according to the EPS concentration were observed. It was observed that the viscosity was influenced by process parameters such as temperature and $\mathrm{pH}$. Indeed, at the same shear rate, viscosity decreased with increasing temperature maybe in relation to an increase in molecular flexibility and loosened polymer structure at higher temperatures [88]. It was also observed that the viscosity of EPS decreased as $\mathrm{pH}$ increased from 3.0 to 9.0, in line with previous studies on Sporidiobolus pararoseus EPSs [89].

\subsubsection{Syneresis}

The application of EPSs in the dairy industry is of high interest, especially for beverages and fermented milk products with the aim of reducing the amount of added milk solids. EPSs are able to texturize these products by improving viscosity without affecting aroma or taste and by reducing syneresis occurring along the fermentation process. However, these properties have only been connected to HePSs so far since they are characterized by high intrinsic viscosities linked to their $\beta(1 \rightarrow 4)$ linkages, leading to the formation of EPS solutions with high consistency, and by branching degree, which is directly related to the polymer stiffness [90].

\section{Conclusions}

The properties of HoPSs in food products open new opportunities for functional food development through their textural effects. As such, their use in plant-based foods aiming to mimic fermented dairy products or in cereal and legume flours as a natural alternative to additives, arouses growing interest. While they are composed of a single type of monosaccharide, the diversity of structures observed for these molecules is large, with a manifold combination of basic units and linkages leading to multiple linear or ramified chains, and various molecular weights. These factors on top of the yield of production strongly influence the HoPS characteristics.

A majority of the data concerns the culture media, and further investigations will be required before being able to predict the in situ HoPS production level, structure and functional effects according to the food matrixes and the sequence of the gene encoding glycosyl hydrolase. Nevertheless, production in foods can be controlled by the bacterial strain and the optimization of incubation parameters for bacterial growth and glycosyl hydrolase enzymes' stability. Sugar availability as a substrate and enzyme activity are crucial for HoPS production in order to control the composition and environment of the food and to optimize the production.

Author Contributions: Funding acquisition, D.S. and F.R.; conceptualization, writing-original draft preparation, M.N., C.G., M.G. and F.R.; writing-review and editing, all authors. All authors have read and agreed to the published version of the manuscript. 
Funding: This research was funded by bilateral funding France-South Africa from Campus France, PHC PROTEA 2019, grant number 42165TF.

Institutional Review Board Statement: Not applicable.

Informed Consent Statement: Not applicable.

Data Availability Statement: No new data were created or analyzed in this study.

Conflicts of Interest: The authors declare no conflict of interest.

\section{References}

1. Ramawat, K.G.; Merillon, J.-M. Polysaccharides: Bioactivity and Biotechnology; Springer: Cham, Switzerland, 2015.

2. Kim, M.J.; Seo, H.N.; Hwang, T.S.; Lee, S.H.; Park, D.H. Characterization of exopolysaccharide (EPS) produced by Weissella hellenica SKkimchi3 isolated from kimchi. J. Microbiol. 2008, 46, 535-541. [CrossRef] [PubMed]

3. Shih, I.-L.; Chen, L.-D.; Wu, J.-Y. Levan production using Bacillus subtilis natto cells immobilized on alginate. Carbohydr. Polym. 2010, 82, 111-117. [CrossRef]

4. Ye, G.; Chen, Y.; Wang, C.; Yang, R.; Bin, X. Purification and characterization of exopolysaccharide produced by Weissella cibaria YB-1 from pickle Chinese cabbage. Int. J. Biol. Macromol. 2018, 120, 1315-1321. [CrossRef]

5. Adebayo-Tayo, B.; Ishola, R.; Oyewunmi, T. Characterization, antioxidant and immunomodulatory potential on exopolysaccharide produced by wild type and mutant Weissella confusa strains. Biotechnol. Rep. 2018, 19, e00271. [CrossRef]

6. Lakra, A.K.; Domdi, L.; Tilwani, Y.M.; Arul, V. Physicochemical and functional characterization of mannan exopolysaccharide from Weissella confusa MD1 with bioactivities. Int. J. Biol. Macromol. 2020, 143, 797-805. [CrossRef]

7. Rosca, I.; Petrovici, A.R.; Peptanariu, D.; Nicolescu, A.; Dodi, G.; Avadanei, M.; Ivanov, I.C.; Bostanaru, A.C.; Mares, M.; Ciolacu, D. Biosynthesis of dextran by Weissella confusa and its in vitro functional characteristics. Int. J. Biol. Macromol. 2018, 107, 1765-1772. [CrossRef] [PubMed]

8. Lynch, K.M.; Zannini, E.; Coffey, A.; Arendt, E.K. Lactic acid bacteria exopolysaccharides in foods and beverages: Isolation, properties, characterization, and health benefits. Annu. Rev. Food Sci. Technol. 2018, 9, 155-176. [CrossRef]

9. Rana, S.; Upadhyay, L.S.B. Microbial exopolysaccharides: Synthesis pathways, types and their commercial applications. Int. J. Biol. Macromol. 2020, 157, 577-583. [CrossRef]

10. Duboc, P.; Mollet, B. Applications of exopolysaccharides in the dairy industry. Int. Dairy J. 2001, 11, 759-768. [CrossRef]

11. Galle, S.; Schwab, C.; Dal Bello, F.; Coffey, A.; Gänzle, M.G.; Arendt, E.K. Influence of in-situ synthesized exopolysaccharides on the quality of gluten-free sorghum sourdough bread. Int. J. Food Microbiol. 2012, 155, 105-112. [CrossRef] [PubMed]

12. Wolter, A.; Hager, A.-S.; Zannini, E.; Czerny, M.; Arendt, E.K. Influence of dextran-producing Weissella cibaria on baking properties and sensory profile of gluten-free and wheat breads. Int. J. Food Microbiol. 2014, 172, 83-91. [CrossRef] [PubMed]

13. Zannini, E.; Mauch, A.; Galle, S.; Gänzle, M.; Coffey, A.; Arendt, E.K.; Taylor, J.P.; Waters, D.M. Barley malt wort fermentation by exopolysaccharide-forming Weissella cibaria MG1 for the production of a novel beverage. J. Appl. Microbiol. 2013, 115, $1379-1387$. [CrossRef] [PubMed]

14. Sengupta, D.; Datta, S.; Biswas, D. Towards a better production of bacterial exopolysaccharides by controlling genetic as well as physico-chemical parameters. Appl. Microbiol. Biotechnol. 2018, 102, 1587-1598. [CrossRef] [PubMed]

15. Lobo, R.E.; Figueroa, T.; Navarro, D.; Gómez, M.I.; Font de Valdez, G.; Torino, M.I. Techno-functional properties of HoPS from lactic acid bacteria of different origins as potential food additives. Food Chem. 2021, 356, 129627. [CrossRef]

16. Van Hijum, S.A.; Kralj, S.; Ozimek, L.K.; Dijkhuizen, L.; Van Geel-Schutten, I.G. Structure-function relationships of glucansucrase and fructansucrase enzymes from lactic acid bacteria. Microbiol. Mol. Biol. Rev. 2006, 70, 157-176. [CrossRef] [PubMed]

17. Kralj, S.; Stripling, E.; Sanders, P.; Van Geel-Schutten, G.H.; Dijkhuizen, L. Highly hydrolytic reuteransucrase from probiotic Lactobacillus reuteri strain ATCC 55730. Appl. Environ. Microbiol. 2005, 71, 3942-3950. [CrossRef] [PubMed]

18. Van Hijum, S.A.F.T.; Szalowska, E.; Van der Maarel, M.J.E.C.; Dijkhuizen, L.Y. Biochemical and molecular characterization of a levansucrase from Lactobacillus reuteri. Microbiology 2004, 150, 621-630. [CrossRef] [PubMed]

19. Semor, N.; Azmi, W.; Gautam, M. Characterization and structural analysis of unique dextran synthesized by purified dextransucrase of newly isolated Acetobacter tropicalis. Curr. Biotechnol. 2018, 7, 376-386. [CrossRef]

20. Vuillemin, M.; Grimaud, F.; Claverie, M.; Rolland-Sabaté, A.; Garnier, C.; Lucas, P.; Monsan, P.; Dols-Lafargue, M.; RemaudSiméon, M.; Moulis, C. A Dextran with unique rheological properties produced by the dextransucrase from Oenococcus kitaharae DSM 17330. Carbohydr. Polym. 2018, 179, 10-18. [CrossRef]

21. Polak-Berecka, M.; Choma, A.; Waśko, A.; Górska, S.; Gamian, A.; Cybulska, J. Physicochemical characterization of exopolysaccharides produced by Lactobacillus rhamnosus on various carbon sources. Carbohydr. Polym. 2015, 117, 501-509. [CrossRef]

22. Du, R.; Xing, H.; Yang, Y.; Jiang, H.; Zhou, Z.; Han, Y. Optimization, purification and structural characterization of a dextran produced by L. mesenteroides isolated from Chinese sauerkraut. Carbohydr. Polym. 2017, 174, 409-416. [CrossRef]

23. Nácher-Vázquez, M.; Iturria, I.; Zarour, K.; Mohedano, M.L.; Aznar, R.; Pardo, M.Á.; López, P. Dextran production by Lactobacillus sakei MN1 coincides with reduced autoagglutination, biofilm formation and epithelial cell adhesion. Carbohydr. Polym. 2017, 168, 22-31. [CrossRef] 
24. Zarour, K.; Llamas, M.G.; Prieto, A.; Rúas-Madiedo, P.; Dueñas, M.T.; De Palencia, P.F.; Aznar, R.; Kihal, M.; López, P. Rheology and bioactivity of high molecular weight dextrans synthesised by lactic acid bacteria. Carbohydr. Polym. 2017, 174, 646-657. [CrossRef]

25. Fraunhofer, M.E.; Geissler, A.J.; Wefers, D.; Bunzel, M.; Jakob, F.; Vogel, R.F. Characterization of $\beta$-glucan formation by Lactobacillus brevis TMW 1.2112 isolated from slimy spoiled beer. Int. J. Biol. Macromol. 2018, 107, 874-881. [CrossRef]

26. Polak-Berecka, M.; Waśko, A.; Kubik-Komar, A. Optimization of culture conditions for exopolysaccharide production by a probiotic strain of Lactobacillus rhamnosus E/N. Pol. J. Microbiol. 2014, 63, 253-257. [CrossRef]

27. Ni, D.; Zhu, Y.; Xu, W.; Bai, Y.; Zhang, T.; Mu, W. Biosynthesis of inulin from sucrose using inulosucrase from Lactobacillus gasseri DSM 20604. Int. J. Biol. Macromol. 2018, 109, 1209-1218. [CrossRef] [PubMed]

28. Kavitake, D.; Devi, P.B.; Singh, S.P.; Shetty, P.H. Characterization of a novel galactan produced by Weissella confusa KR780676 from an acidic fermented food. Int. J. Biol. Macromol. 2016, 86, 681-689. [CrossRef] [PubMed]

29. Vettori, M.H.P.B.; Franchetti, S.M.M.; Contiero, J. Structural characterization of a new dextran with a low degree of branching produced by Leuconostoc mesenteroides FT045B dextransucrase. Carbohydr. Polym. 2012, 88, 1440-1444. [CrossRef]

30. Oleksy, M.; Klewicka, E. Exopolysaccharides produced by Lactobacillus pp.: Biosynthesis and applications. Crit. Rev. Food Sci. Nutr. 2018, 58, 450-462. [CrossRef]

31. Meng, X.; Gangoiti, J.; Bai, Y.; Pijning, T.; Van Leeuwen, S.S.; Dijkhuizen, L. Structure-function relationships of family GH70 glucansucrase and 4,6- $\alpha$-glucanotransferase enzymes, and their evolutionary relationships with family GH13 enzymes. Cell Mol. Life Sci. 2016, 73, 2681-2706. [CrossRef]

32. Wang, C.; Zhang, H.; Li, M.; Hu, X.; Li, Y. Functional analysis of truncated and site-directed mutagenesis dextransucrases to produce different type dextrans. Enzym. Microb. Technol. 2017, 102, 26-34. [CrossRef] [PubMed]

33. Claverie, M.; Cioci, G.; Vuillemin, M.; Bondy, P.; Remaud-Simeon, M.; Moulis, C. Processivity of dextransucrases synthesizing very-high-molar-mass dextran is mediated by sugar-binding pockets in domain V. J. Biol. Chem. 2020, 295, 5602-5613. [CrossRef]

34. Meng, X.; Dobruchowska, J.M.; Pijning, T.; López, C.A.; Kamerling, J.P.; Dijkhuizen, L. Residue Leu940 has a crucial role in the linkage and reaction specificity of the glucansucrase GTF180 of the probiotic bacterium Lactobacillus reuteri 180. J. Biol. Chem. 2014, 289, 32773-32782. [CrossRef]

35. Molina, M.; Moulis, C.; Monties, N.; Pizzut-Serin, S.; Guieysse, D.; Morel, S.; Cioci, G.; Remaud-Siméon, M. Deciphering an undecided enzyme: Investigations of the structural determinants involved in the linkage specificity of alternansucrase. ACS Catal. 2019, 9, 2222-2237. [CrossRef]

36. Badel, S.; Bernardi, T.; Michaud, P. New perspectives for Lactobacilli exopolysaccharides. Biotechnol. Adv. 2011, $29,54-66$. [CrossRef] [PubMed]

37. Schmid, J.; Bechtner, J.; Vogel, R.F.; Jakob, F. A systematic approach to study the pH-dependent release, productivity and product specificity of dextransucrases. Microb. Cell Factories 2019, 18, 153. [CrossRef] [PubMed]

38. Hu, Y.; Gänzle, M.G. Effect of temperature on production of oligosaccharides and dextran by Weissella cibaria 10 M. Int. J. Food Microbiol. 2018, 280, 27-34. [CrossRef]

39. Schmid, J.; Wefers, D.; Vogel, R.F.; Jakob, F. Analysis of structural and functional differences of glucans produced by the natively released dextransucrase of Liquorilactobacillus hordei TMW 1.1822. Appl. Biochem. Biotechnol. 2021, 193, 96-110. [CrossRef]

40. Schlörmann, W.; Bockwoldt, J.A.; Mayr, M.F.; Lorkowski, S.; Dawczynski, C.; Rohn, S.; Ehrmann, M.A.; Glei, M. Fermentation profile, cholesterol-reducing properties and chemopreventive potential of $\beta$-glucans from Levilactobacillus brevis and Pediococcus claussenii-A comparative study with $\beta$-glucans from different sources. Food Funct. 2021, 12, 10615-10631. [CrossRef]

41. Dols Lafargue, M. Polysaccharide production by wine lactic acid bacteria: Negative trait or potential advantage? A review. Appli Micro Open Access 2018, 4, 1-8. [CrossRef]

42. Walling, E.; Gindreau, E.; Lonvaud-funel, A. A putative glucan synthase gene Dps detected in exopolysaccharide-producing Pediococcus damnosus and Oenococcus oeni strains isolated from wine and cider. Int. J. Food Microbiol. 2005, 98, 53-62. [CrossRef] [PubMed]

43. Dueñas-Chasco, M.T.; Rodríguez-Carvajal, M.A.; Tejero-Mateo, P.; Espartero, J.L.; Irastorza-Iribas, A.; Gil-Serrano, A.M. Structural analysis of the exopolysaccharides produced by Lactobacillus spp. G-77. Carbohydr. Res. 1998, 307, 125-133. [CrossRef]

44. Gullo, M.; La China, S.; Falcone, P.M.; Giudici, P. Biotechnological production of cellulose by acetic acid bacteria: Current state and perspectives. Appl. Microbiol. Biotechnol. 2018, 102, 6885-6898. [CrossRef] [PubMed]

45. Mudgil, D. Chapter 3-The interaction between insoluble and soluble fiber. In Dietary Fiber for the Prevention of Cardiovascular Disease; Samaan, R.A., Ed.; Academic Press: Cambridge, MA, USA, 2017; pp. 35-59. ISBN 978-0-12-805130-6.

46. Peesapati, S.; Sajeevan, K.A.; Patel, S.K.; Roy, D. Relation between glycosidic linkage, structure and dynamics of $\alpha$ - and $\beta$-glucans in water. Biopolymers 2021, 112, e23423. [CrossRef] [PubMed]

47. Harutoshi, T. Exopolysaccharides of Lactic Acid Bacteria for Food and Colon Health Applications; IntechOpen: London, UK, 2013; ISBN 978-953-51-0955-6.

48. Monsan, P.; Bozonnet, S.; Albenne, C.; Joucla, G.; Willemot, R.-M.; Remaud-Siméon, M. Homopolysaccharides from lactic acid bacteria. Int. Dairy J. 2001, 11, 675-685. [CrossRef]

49. Pomin, V.H.; Mourão, P.A.S. Structure, biology, evolution, and medical importance of sulfated fucans and galactans. Glycobiology 2008, 18, 1016-1027. [CrossRef] 
50. Zeidan, A.A.; Poulsen, V.K.; Janzen, T.; Buldo, P.; Derkx, P.M.F.; Øregaard, G.; Neves, A.R. Polysaccharide production by lactic acid bacteria: From Genes to industrial applications. FEMS Microbiol. Rev. 2017, 41, S168-S200. [CrossRef]

51. Zhou, Y.; Cui, Y.; Qu, X. Exopolysaccharides of lactic acid bacteria: Structure, bioactivity and associations: A review. Carbohydr. Polym. 2019, 207, 317-332. [CrossRef] [PubMed]

52. Guérin, M.; Silva, C.R.-D.; Garcia, C.; Remize, F. Lactic acid bacterial production of exopolysaccharides from fruit and vegetables and associated benefits. Fermentation 2020, 6, 115. [CrossRef]

53. Årsköld, E.; Svensson, M.; Grage, H.; Roos, S.; Rådström, P.; Van Niel, E.W.J. Environmental influences on exopolysaccharide formation in Lactobacillus reuteri ATCC 55730. Int. J. Food Microbiol. 2007, 116, 159-167. [CrossRef] [PubMed]

54. Miao, M.; Ma, Y.; Huang, C.; Jiang, B.; Cui, S.W.; Zhang, T. Physicochemical properties of a water soluble extracellular homopolysaccharide from Lactobacillus reuteri SK24.003. Carbohydr. Polym. 2015, 131, 377-383. [CrossRef]

55. Looijesteijn, P.J.; Casteren, W.H.M.V.; Tuinier, R.; Doeswijk-Voragen, C.H.L.; Hugenholtz, J. Influence of different substrate limitations on the yield, composition and molecular mass of exopolysaccharides produced by Lactococcus lactis subsp. cremoris in continuous cultures. J. Appl. Microbiol. 2000, 89, 116-122. [CrossRef]

56. Van Geel-Schutten, G.H.; Flesch, F.; Ten Brink, B.; Smith, M.R.; Dijkhuizen, L. Screening and characterization of Lactobacillus strains producing large amounts of exopolysaccharides. Appl. Microbiol. Biotechnol. 1998, 50, 697-703. [CrossRef]

57. Wolter, A.; Hager, A.-S.; Zannini, E.; Galle, S.; Gänzle, M.G.; Waters, D.M.; Arendt, E.K. Evaluation of exopolysaccharide producing Weissella cibaria MG1 strain for the production of sourdough from various flours. Food Microbiol. 2014, 37, 44-50. [CrossRef] [PubMed]

58. Galle, S.; Schwab, C.; Arendt, E.; Gänzle, M. Exopolysaccharide-forming Weissella strains as starter cultures for sorghum and wheat sourdoughs. J. Agric. Food Chem. 2010, 58, 5834-5841. [CrossRef] [PubMed]

59. Yilmaz, M.T.; Dertli, E.; Toker, O.S.; Tatlisu, N.B.; Sagdic, O.; Arici, M. Effect of in situ exopolysaccharide production on physicochemical, rheological, sensory, and microstructural properties of the yogurt drink Ayran: An optimization study based on fermentation kinetics. J. Dairy Sci. 2015, 98, 1604-1624. [CrossRef]

60. Xu, Y.; Wang, Y.; Coda, R.; Säde, E.; Tuomainen, P.; Tenkanen, M.; Katina, K. In situ synthesis of exopolysaccharides by Leuconostoc spp. and Weissella spp. and their rheological impacts in fava bean flour. Int. J. Food Microbiol. 2017, 248, 63-71. [CrossRef]

61. Galli, V.; Venturi, M.; Coda, R.; Maina, N.H.; Granchi, L. Isolation and characterization of indigenous Weissella confusa for in situ bacterial exopolysaccharides (EPS) production in chickpea sourdough. Food Res. Int. 2020, 138, 109785. [CrossRef]

62. Meng, Q.; Lu, C.; Gao, H.; Chen, G.; Wu, L.; Wu, J.; Li, S.; He, B.-F. Efficient biosynthesis of exopolysaccharide from Jerusalem artichoke using a novel strain of Bacillus velezensis LT-2. Bioresour. Technol. 2021, 320, 124346. [CrossRef]

63. Hilbig, J.; Gisder, J.; Prechtl, R.M.; Herrmann, K.; Weiss, J.; Loeffler, M. Influence of exopolysaccharide-producing lactic acid bacteria on the spreadability of fat-reduced raw fermented sausages (Teewurst). Food Hydrocoll. 2019, 93, 422-431. [CrossRef]

64. Perri, G.; Coda, R.; Rizzello, C.G.; Celano, G.; Ampollini, M.; Gobbetti, M.; De Angelis, M.; Calasso, M. Sourdough fermentation of whole and sprouted lentil flours: In situ formation of dextran and effects on the nutritional, texture and sensory characteristics of white bread. Food Chem. 2021, 355, 129638. [CrossRef]

65. Hickisch, A.; Beer, R.; Vogel, R.F.; Toelstede, S. Influence of lupin-based milk alternative heat treatment and exopolysaccharideproducing lactic acid bacteria on the physical characteristics of lupin-based yogurt alternatives. Food Res. Int. 2016, 84, 180-188. [CrossRef]

66. Düven, G.; Kumcuoğlu, S.; Kışla, D. Ultrasonication-assisted kefir production and its effect on fermentation time and EPS production. Food Biosci. 2021, 42, 101059. [CrossRef]

67. Dertli, E.; Yilmaz, M.T.; Tatlisu, N.B.; Toker, O.S.; Cankurt, H.; Sagdic, O. Effects of in situ exopolysaccharide production and fermentation conditions on physicochemical, microbiological, textural and microstructural properties of Turkish-type fermented sausage (Sucuk). Meat Sci. 2016, 121, 156-165. [CrossRef] [PubMed]

68. Abedfar, A.; Hosseininezhad, M.; Sadeghi, A.; Raeisi, M.; Feizy, J. Investigation on "spontaneous fermentation" and the productivity of microbial exopolysaccharides by Lactobacillus plantarum and Pediococcus pentosaceus isolated from wheat bran sourdough. LWT 2018, 96, 686-693. [CrossRef]

69. Dertli, E.; Mercan, E.; Arıcı, M.; Yılmaz, M.T.; Sağdıç, O. Characterisation of lactic acid bacteria from Turkish sourdough and determination of their exopolysaccharide (EPS) production characteristics. LWT-Food Sci. Technol. 2016, 71, 116-124. [CrossRef]

70. Katina, K.; Maina, N.H.; Juvonen, R.; Flander, L.; Johansson, L.; Virkki, L.; Tenkanen, M.; Laitila, A. In situ production and analysis of Weissella confusa dextran in wheat sourdough. Food Microbiol. 2009, 26, 734-743. [CrossRef]

71. Rühmkorf, C.; Rübsam, H.; Becker, T.; Bork, C.; Voiges, K.; Mischnick, P.; Brandt, M.J.; Vogel, R.F. Effect of structurally different microbial homoexopolysaccharides on the quality of gluten-free bread. Eur. Food Res. Technol. 2012, 235, 139-146. [CrossRef]

72. Xu, Y.; Coda, R.; Holopainen-Mantila, U.; Laitila, A.; Katina, K.; Tenkanen, M. Impact of in situ produced exopolysaccharides on rheology and texture of fava bean protein concentrate. Food Res. Int. 2019, 115, 191-199. [CrossRef]

73. Lorusso, A.; Coda, R.; Montemurro, M.; Rizzello, C. Use of selected lactic acid bacteria and quinoa flour for manufacturing novel yogurt-like beverages. Foods 2018, 7, 51. [CrossRef] [PubMed]

74. Korcz, E.; Varga, L. Exopolysaccharides from lactic acid bacteria: Techno-functional application in the food industry. Trends Food Sci. Technol. 2021, 110, 375-384. [CrossRef] 
75. Llamas-Arriba, M.G.; Peirotén, Á.; Puertas, A.I.; Prieto, A.; López, P.; Pardo, M.Á.; Rodríguez, E.; Dueñas, M.T. Heteropolysaccharide-producing bifidobacteria for the development of functional dairy products. LWT 2019, 102, 295303. [CrossRef]

76. Nachtigall, C.; Surber, G.; Herbi, F.; Wefers, D.; Jaros, D.; Rohm, H. Production and molecular structure of heteropolysaccharides from two lactic acid bacteria. Carbohydr. Polym. 2020, 236, 116019. [CrossRef] [PubMed]

77. Kant Bhatia, S.; Gurav, R.; Choi, Y.-K.; Choi, T.-R.; Kim, H.; Song, H.-S.; Mi Lee, S.; Lee Park, S.; Soo Lee, H.; Kim, Y.-G.; et al. Bioprospecting of exopolysaccharide from marine Sphingobium yanoikuyae BBL01: Production, characterization, and metal chelation activity. Bioresour. Technol. 2021, 324, 124674. [CrossRef]

78. EUR-Lex-32001D0122. Commission Decision of 30 January 2001 on Authorising the Placing on the Market of a Dextran Preparation Produced by Leuconostoc Mesenteroides as a Novel Food Ingredient in Bakery Products under Regulation (EC) No 258/97 of the European Parliament and of the Council (Notified under Document Number C(2001) 174); European Parliament: Strasbourg, France, 2001.

79. Caggianiello, G.; Kleerebezem, M.; Spano, G. Exopolysaccharides produced by lactic acid bacteria: From health-promoting benefits to stress tolerance mechanisms. Appl. Microbiol. Biotechnol. 2016, 100, 3877-3886. [CrossRef]

80. Arendt, E.K.; Ryan, L.A.M.; Dal Bello, F. Impact of sourdough on the texture of bread. Food Microbiol. 2007, 24, 165-174. [CrossRef]

81. Birch, J.; Van Calsteren, M.-R.; Pérez, S.; Svensson, B. The exopolysaccharide properties and structures database: EPS-DB. Application to bacterial exopolysaccharides. Carbohydr. Polym. 2019, 205, 565-570. [CrossRef]

82. Mende, S.; Rohm, H.; Jaros, D. Influence of exopolysaccharides on the structure, texture, stability and sensory properties of yoghurt and related products. Int. Dairy J. 2016, 52, 57-71. [CrossRef]

83. Benigar, E.; Dogsa, I.; Stopar, D.; Jamnik, A.; Cigić, I.K.; Tomšič, M. Structure and dynamics of a polysaccharide matrix: Aqueous solutions of bacterial levan. Langmuir 2014, 30, 4172-4182. [CrossRef]

84. Xu, Y.; Pitkänen, L.; Maina, N.H.; Coda, R.; Katina, K.; Tenkanen, M. Interactions between fava bean protein and dextrans produced by Leuconostoc pseudomesenteroides DSM 20193 and Weissella cibaria Sj 1b. Carbohydr. Polym. 2018, 190, 315-323. [CrossRef]

85. Kasaai, M.R. Dilute solution properties and degree of chain branching for dextran. Carbohydr. Polym. 2012, 88, 373-381. [CrossRef]

86. Hundschell, C.S.; Wagemans, A.M. Rheology of common uncharged exopolysaccharides for food applications. Curr. Opin. Food Sci. 2019, 27, 1-7. [CrossRef]

87. Bejar, W.; Gabriel, V.; Amari, M.; Morel, S.; Mezghani, M.; Maguin, E.; Fontagné-Faucher, C.; Bejar, S.; Chouayekh, H. Characterization of glucansucrase and dextran from Weissella sp. TN610 with potential as safe food additives. Int. J. Biol. Macromol. 2013, 52, 125-132. [CrossRef] [PubMed]

88. Wang, B.; Song, Q.; Zhao, F.; Xiao, H.; Zhou, Z.; Han, Y. Purification and characterization of dextran produced by Leuconostoc pseudomesenteroides PC as a potential exopolysaccharide suitable for food applications. Process Biochem. 2019, 87, 187-195. [CrossRef]

89. Han, M.; Du, C.; Xu, Z.-Y.; Qian, H.; Zhang, W.-G. Rheological properties of phosphorylated exopolysaccharide produced by Sporidiobolus pararoseus JD-2. Int. J. Biol. Macromol. 2016, 88, 603-613. [CrossRef] [PubMed]

90. Daba, G.M.; Elnahas, M.O.; Elkhateeb, W.A. Contributions of exopolysaccharides from lactic acid bacteria as biotechnological tools in food, pharmaceutical, and medical applications. Int. J. Biol. Macromol. 2021, 173, 79-89. [CrossRef] 